double ventral line. The lower two of the side lines are somewhat broken by large white spots on the anterior portion of joints 6 and 7. Lines lost on the thorax. Other examples are more heavily shaded with dark brown so that the lines are broken, especially centrally on the segments.

Stage IV. Head flat before, sides and vertex continuous and of even width, a slight shallow notch. Face with an irregular pale mark composed of a white clypeus and four confluent dots, surrounded by a dark brown border, dotted with white; sides and vertex white, mottled with brown, especially in the center of the side posteriorly and in vertical notch; width about $\mathrm{x} .5 \mathrm{~mm}$. Body cylindrical with slight subventral ridge, thorax somewhat smaller; anal plate large, triangular, not cornified; tubercle iii in a slightly elevated black spot. Brown, finely streaked longitudinally with white, intermixed with a few black dots. An obscurely double, blackish dorsal line, each side of which on joints 6,7 and 8 are two white dots, the anterior one nearest the line. Thorax subventrally and a dot before the spiracle on joint 5 , an oblique subventral dash on joints 5 to ro and joints i 1 to 13 subventrally black. All rather obscurely marked, brown, resembling bark. During the stage the color pales to an almost whitish brown making the white linings obscure and the black dots prominent.

Stage $V$. Head as before, the sides and vertex pale, faintly marbled with pale luteous; width about $2 \mathrm{~mm}$. Body straight, cylindrical, rather short and robust, smaller than the head; a slight dorsal elevation on joint 12 composed of the prominent tubercles i; anal plate and leg shields large. Pale wood brown, speckled with black; i. e. the tubercles and some irregular dots, besides a narrow double dorsal line, black. The line is pulverulent and fainter in the incisures. A similar, browner ventral line. Feet pale; a dark subventral shade on thorax. Setae obscure; dorsal tubercles a little prominent.

Stage VI. Head square, face flat, rounded, slightly narrowed above; broadly, shallowly bilobed, equal in thickness above and below; clypeus high, the paraclypeal pieces reaching the vertical notch; width $2.8 \mathrm{~mm}$. Color pale wood brown, face strongly mottled with dark brown around the margin; clypeus and an area on either side pale; sides faintly marbled with pale brown, most distinctly on vertex. Body cylindrical, rather robust, neck slightly narrowed; smooth, tubercles i on joint 12 produced; subventral fold slightly prominent, waved; anal shields large, rounded. Thoracic feet rather small, equal. Pale wood brown, faintly mottled with redbrown; a narrow, geminate, pulverulent, black dorsal line, slightly broadening into a shade on joints 12 and 13 . Medio-ventral line pale and reddish; a broad, double, diffuse, shaded subventral black band. Tubercles and several dots-in lateral region black, spiracles black ringed; feet slightly lined with black at base. Variation not marked. The lateral dots may be faint or distinct, rarely connected into a broad lateral shade, bordered above by a waved subdorsal line and reaching over lateral region to below subventral fold. The usual form is pale brown with single dorsal and paired subventral blackish bands; tubercles $\mathrm{i}$ of joint $\mathrm{x} 2$ conically produced.

Cocoon a coarse net of brown silk between leaves. The larvae refused oak, but fed readily on persimmon and apple. Found at Brookhaven, Long Island, N. Y., eggs June Ioth, mature larvae August ioth.

\section{A NEW MELOID BEETLE PARASITIC ON ANTHOPHORA.}

Leonia neomexicana, $\mathrm{n}$. sp. - Length about II millim. Black, including legs and antennae; elytra fulvous. Form of $L$. rileyi, with a rather sparse black pubescence; mandibles stout, curved, entire, blunt at tip; antennae stout, ro-jointed, first joint campanulate, shorter and more abruptly swollen 
distally than in rileyi; second and third joints equilateral like the following ones, not oblique with one side produced as in rileyi; second joint sensibly shorter than the third; third slightly longer than the fourth; fourth to ninth about equal in length, but the distal joints narrower than the proximal; terminal joint similar to the penultimate one, whereas in rileyi the last two joints are dissimilar. Prothorax as in rileyi, shining, sparsely punctured; elytra about as in rileyi; covering at the sides about two-thirds of the first abdominal segment. Hind margins of abdominal segments narrowly testaceous; surface of segments shining, with broad shallow punctures. At the sides the ventral segments encroach upon the dorsal area, the dorsoventral sutures being marked by deep sublateral channels. Legs as in rileyi; claws simple, with a strong basal bristle.

Hab. - Mesilla, New Mexico, about the first of August, 1896 , on a wall in which were many nests of Anthophora vallorum (Ckll.). This was sent at the time of its discovery to Dr. Horn, and it is much to be regretted that he did not live to publish an account of it. When recently in Philadelphia, I found it in Dr. Horn's collection, and was able to draw up the above description. L. neomexicana is very distinct from Hornia minutipen$n i s$, and quite sufficiently so from Leonia rileyi, as the following table of the North American Sitarini shows :-

Antennae II-jointed; head, thorax and legs bright ferruginous.

Hornia minutipennis Riley.

Antennae ro-jointed.

Black; elytra fulvous; second and third antennal joints equilateral.

Leonia neomexicana $\mathrm{Ck} 11$. Dark ferruginous; elytra testaceous; second and third antennal joints conspicuously inequilateral

Leonia rileyi E. Dugès. (Mexico.)

All three are parasitic in nests of Anthophora.

N. M. Agr. Exp. Sta.

\section{A NEW PULVINARIA FROM MASSA- CHUSETTS.}

Pulvinaria cockerelli, $n$. sp. $q$ Scale yellowish brown, small, nearly hemispherical in outline, slightly convex, $4 \mathrm{~mm}$. long, 3t $\mathrm{mm}$. broad. Ovisac $7 \mathrm{~mm}$. long, $3 \mathrm{~mm}$. broad and a little more than $\mathbf{I} \mathrm{mm}$. in thickness. Texture soft, clear white, powdery and sticky. Eggs small oval, white, situated in an oval cluster on the under side of the leaf beneath the ovisac. Newly hatched larvae clear white. $\&$ Scale cleared and mounted transparent slightly tinged with yellow. Legs, antennae, mouthparts and anal plates light yellow. Antennae 8 segmented, 3 quite long, 4 next, 7 is the shortest (see table of measurements all in micromillimeters). The hairs on the antennae are as represented in the drawing, usually 18 . The length and breadth of the antennae seem to be quite constant in all of the material examined. Legs normal. Coxa broader than long, the legs usually have about 22 hairs on each (see figure of leg). Marginal spines stout, bulbous

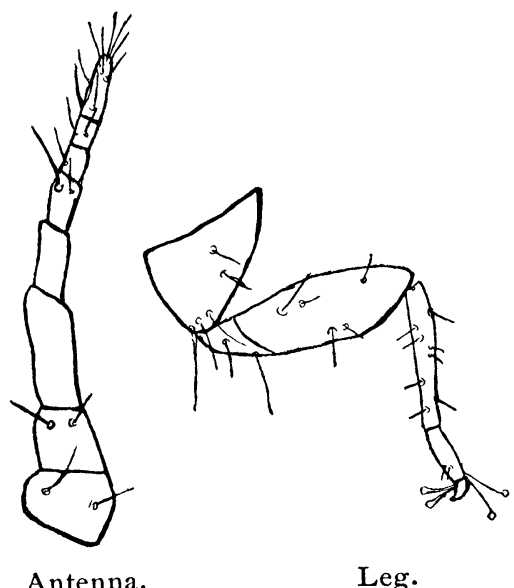

at base, tips sharp, 6 micromillimeters long, they are very easily lost in mounting. 

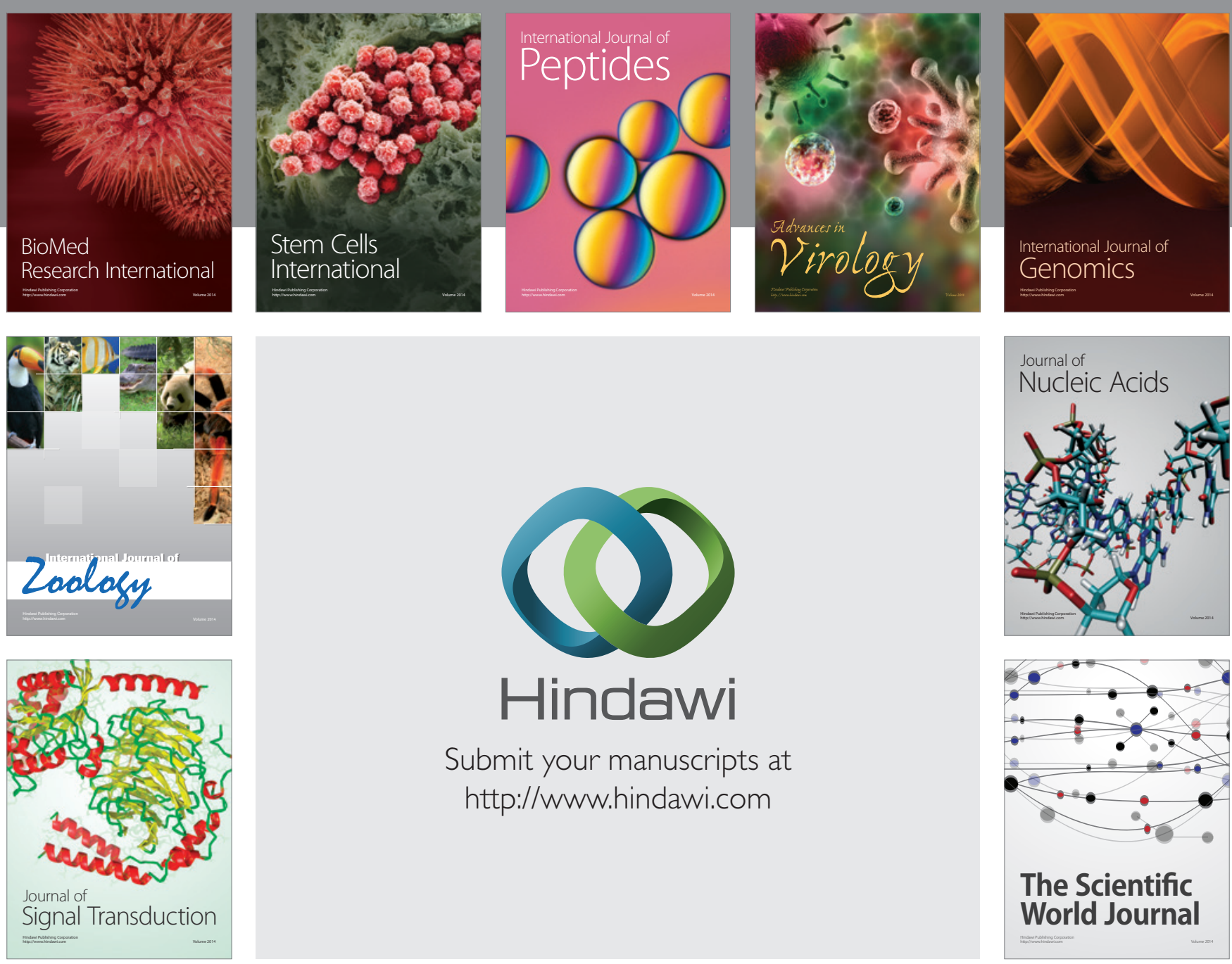

Submit your manuscripts at

http://www.hindawi.com
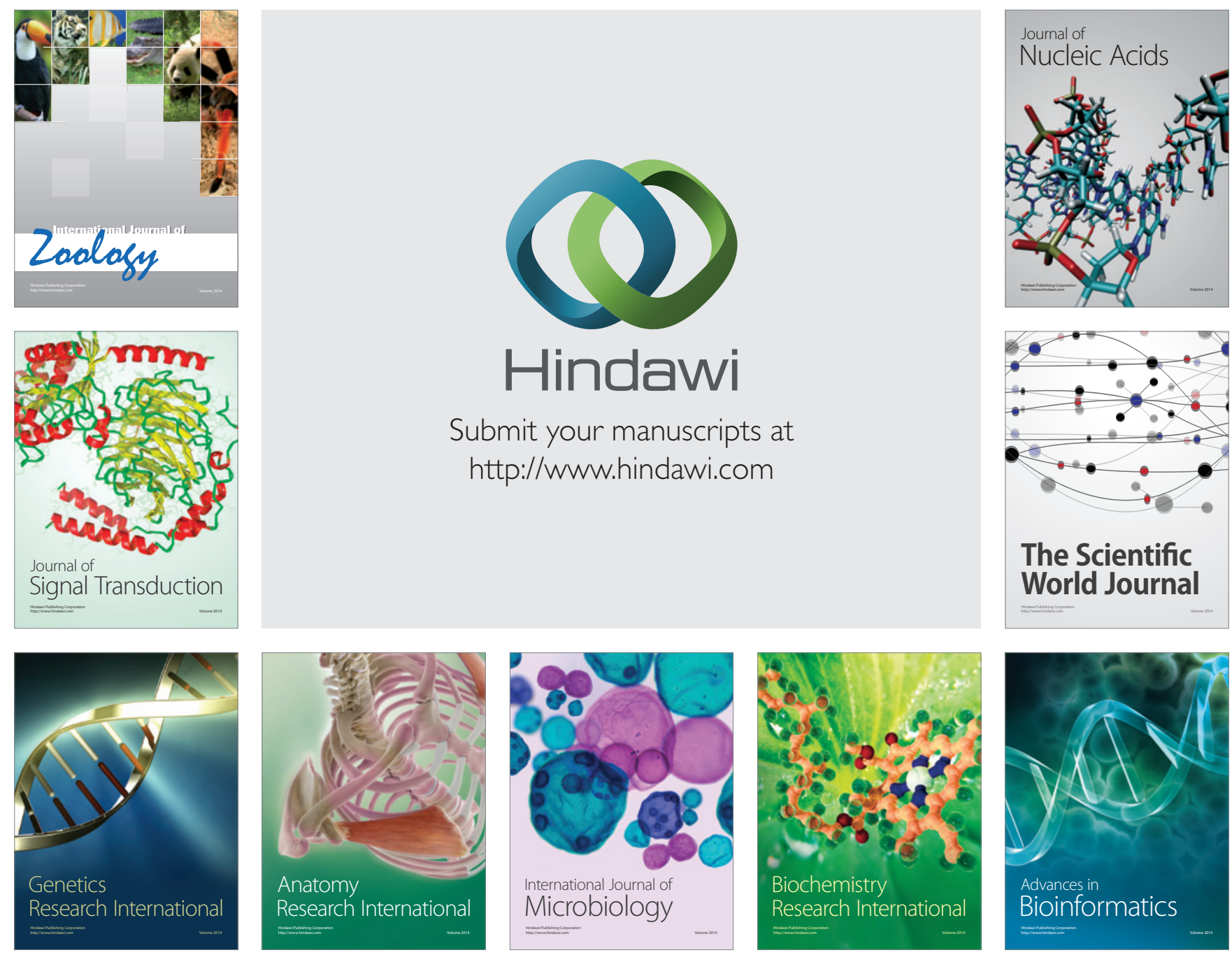

The Scientific World Journal
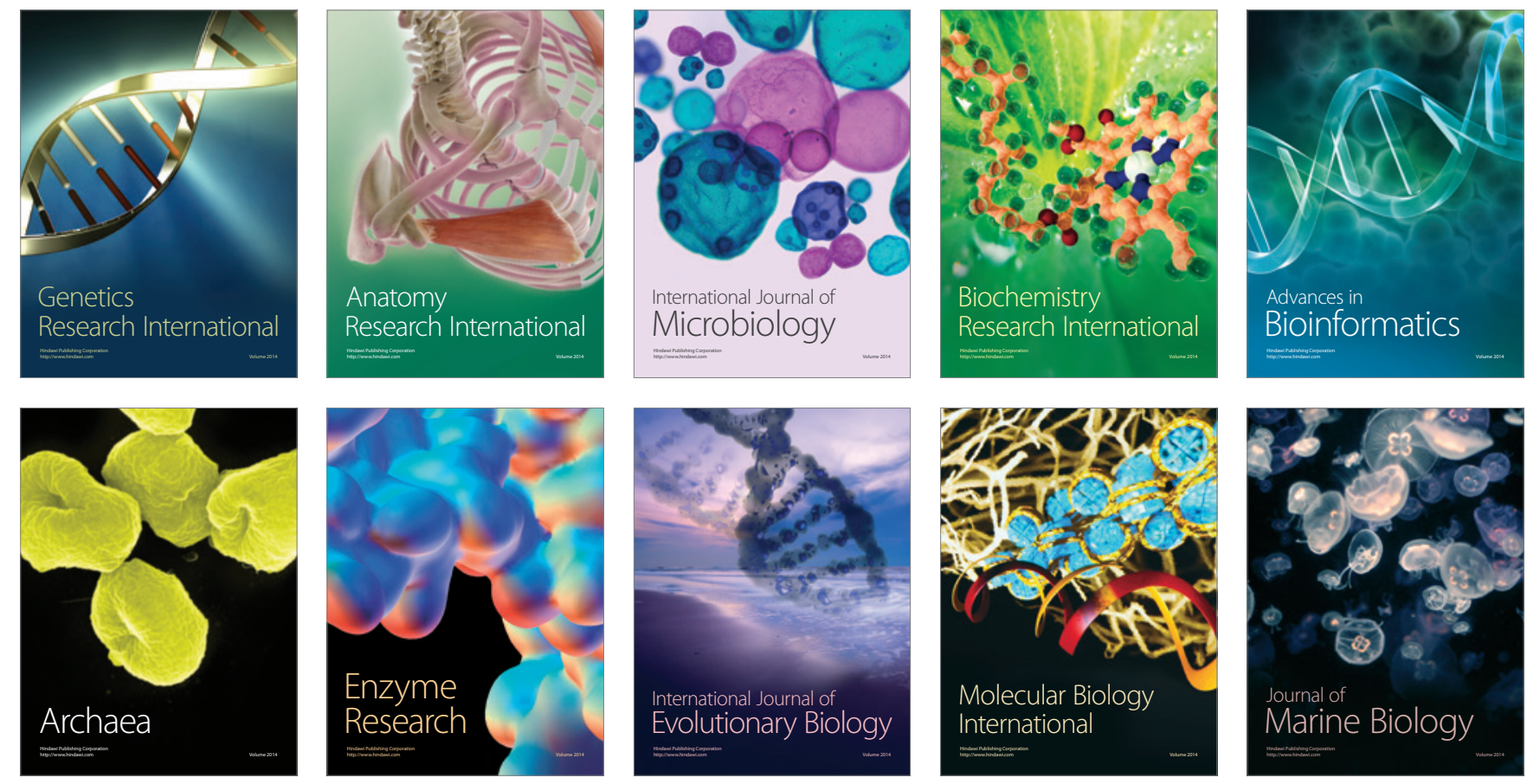